\author{
Полонська О.М. \\ старший науковий співробітник \\ науково-дослідний відділ продуктивності \\ та аналітики статистичної звітності в харчовій \\ і переробній промисловості \\ E-mail: olga polon3@ukr.net \\ ORCID ID: 0000-0002-2432-8540
}

\author{
Солошонок А.Л. \\ завідувач науково-дослідного відділу \\ продуктивності та аналітики статистичної \\ звітності в харчовій і переробній \\ промисловості \\ E-mail: 555860@ukr.net \\ ORCID ID: 0000-0001-8354-7519
}

\author{
Некова Г.П. \\ науковий співробітник \\ науково-дослідний відділ продуктивності та аналітики статистичної звітності \\ в харчовій і переробній промисловості \\ Український науково-дослідний інститут продуктивності агропромислового комплексу \\ Солом'янська площа, 2, м. Київ, Україна, 03035 \\ E-mail: smilealiona@ukr.net \\ ORCID ID: 0000-0001-6797-4502
}

\title{
АНАЛІЗ ОБІГУ ЗЕРНОВИХ ТА ВИРОБНИЦТВА БОРОШНОМЕЛЬНО-КРУП'ЯНОЇ ПРОДУКЦІЇ В УКРАЇНІ
}

\begin{abstract}
Висвітлено стан надходження і перероблення зернових та зернобобових культур на підприємствах, що займаються їхнім зберіганням і переробленням, за перше півріччя 2021 року всього по Україні та в регіональному зрізі. За даний період проаналізовано обсяги та середні ціни реалізації основних зернових та зернобобових культур сільськогосподарськими підприємствами. Сформовано в таблиці і проаналізовано надходження основних зернових культур на переробні підприємства та середні ціни їх купівлі всього по Україні та регіонах. Проведено аналіз щодо загального обсягу перероблених зернових і зернобобових за основними культурами (пшениця, кукурудза, ячмінь) та за основними продуктами (борошно, крупа, комбікорм). Проаналізовано обсяги виробництва основних видів борошномельнокруп'яної продукції та динаміку виробництва борошна і круп. У цілому розкрито специфічні проблеми борошномельно-круп'яної галузі та шляхи їх вирішення. Також наведено рейтинг Топ-10 провідних виробників борошна України.
\end{abstract}

Ключові слова: продовольча безпека, зернові та зернобобові культури, надходження, перероблення, борошномельно-круп'яна продукція, середня ціна, виробництво.

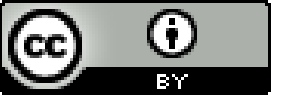

This work is licensed under a Creative Commons Attribution 4.0 International License http://creativecommons.org/licenses/by/4.0/
Постановка проблеми та її зв'язок з важливими науковими та практичними завданнями. Зерновий ринок України - гарант національної продовольчої безпеки і базовий ринок у забезпеченні макроекономічної та соціальної стабільності в суспільстві. Сьогодні зернове господарство демонструє високі темпи виробництва та експорту продукції, водночас перетворитися на один 3 локомотивів економічного зростання держави воно зможе лише за умови збалансованого розвитку суміжних ринків продуктів переробки зерна.

На думку Ольги Трофімцевої, голови правління Асамблеї аграрних палат України, надзвичайно важливими є питання виробництва зерна та його переробки. 3 одного боку, саме ця підгалузь українського АПК приносить левову частку валютних надходжень кожного року, але з іншого боку все більше постають нові питання або нові виклики у галузі. Зернове господарство України стає все більш ефективним і продуктивним, тому потрібно поступово розвивати систему логістичну, інфраструктурну, зберігання, переробки зерна для того, щоб не втрачалися якісні характеристики та показники для покупців даної продукції [1].

Споживачами кінцевої продукції зернової галузі виступають підприємства борошномельно-круп'яної, хлібобулочної, комбікормової промисловості тощо.

Борошномельно-круп'яна промисловість України є соціально значущою для населення, стратегічно важливою і повністю залежить від зернового агропромислового комплексу. Як доводять дослідження, основними видами продуктів, які споживає населення щодня, є крупи та хлібобулочні вироби, що готуються 3 борошна, тому саме борошномельнокруп'яна галузь $\epsilon$ основою продовольчої безпеки населення України. А дослідження стосовно обігу зернових та виробництва борошномельно-круп'яної продукції є актуальними і потребують поглиблення та узагальнення даних для прийняття керівниками підприємств оптимальних рішень при плануванні їх ефективної роботи. 
Аналіз останніх публікацій по проблемі. Питанням ефективності функціонування підприємств зернового комплексу в Україні присвятили свої праці такі вітчизняні вчені, як Калетнік Г. М. [2], Саблук П. Т., Подпрятов Г. І. [3], В. М. Лебідь [4], Кучер М. I., Макаренко П. М, Шпичак О. М. та інші. У роботах зазначених авторів увага приділяється проблемам підвищення економічної ефективності виробництва i переробки зерна, формування й функціонування ринків зерна та продуктів його переробки. Сучасний стан, проблеми та перспективи розвитку борошномельно-круп'яної промисловості висвітлено у працях Кудренко Н. В. [5], Князєва С. І, [6], Царьова В. М. [7], Ляховської О. В.,[8], Камінської А. І.

Водночас, незважаючи на різноманітні підходи до висвітлення питань ефективного функціонування ринку зернових культур та продуктів їх перероблення, залишаються недостатньо висвітлені питання, пов'язані із ув'язуванням виробництва зернових, їх надходження на перероблення і подальшою переробкою на борошномельно-круп'яну продукцію, тому ці питання потребують більш детального дослідження.
Формування цілей дослідження. Мета статті - проаналізувати сучасний стан обігу зернових та зернобобових культур та виробництва борошномельно-круп'яної продукції, перспективи подальшого розвитку галузей, що займаються зберіганням та переробленням зернових та зернобобових культур.

Виклад основних результатів та їх обгрунтування. Підприємства, що займаються зберіганням та переробленням зернових культур, є споживачами продукції рослинництва, виробництво кінцевої продукції цих підприємств майже повністю залежить від рівня збору зернових культур. На сільськогосподарській сировині працюють багато галузей промисловості, однак борошномельно-круп'яна на 100 \% залежна від наявності та надходження зернової сировини. Споживачами ж кінцевої продукції перероблення зернових виступають як підприємства харчової і переробної промисловості, так і домогосподарства населення.

Схема перероблення та споживання готової борошномельно-круп'яної продукції наведена на рис. 1.

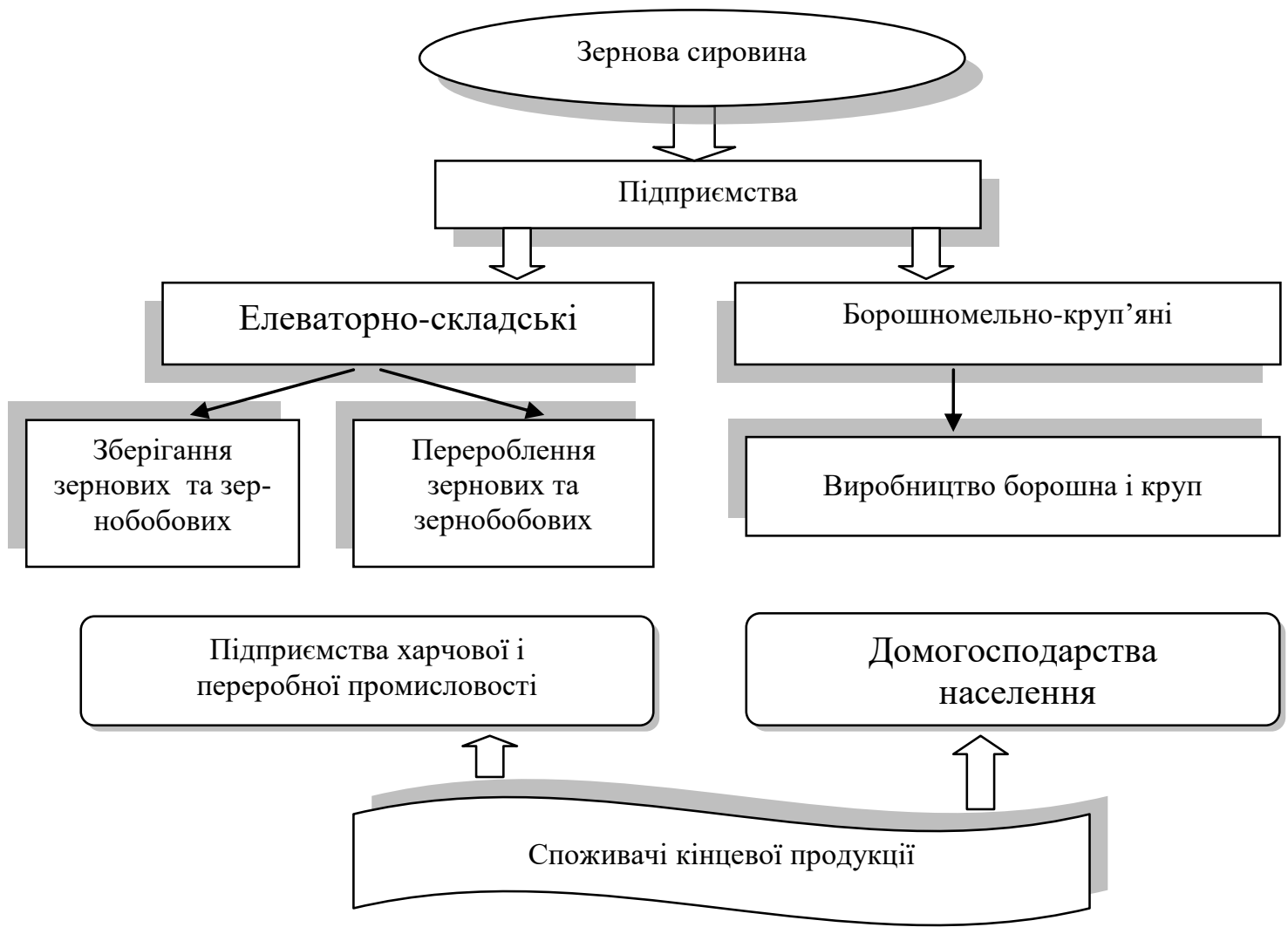

Рис. 1. Перероблення та споживання готової борошномельно-круп'яної продукції *побудовано авторами

Україна повністю забезпечує внутрішній ринок зернових культур. У 2021 році експерти прогнозують рекордний врожай зернових. За попередніми підрахунками очікується, що цьогорічний врожай зернових в Україні досягне показника 75 млн т, а це дає сподівання на непогані ринкові позиції українських товаровиробників [9].
Першочерговим завданням держави є гарантування продовольчої безпеки населення, тому формування достатніх запасів зерна (продовольчого та фуражного) на рівні чотиримісячного запасу внутрішнього споживання є пріоритетним завданням Уряду. Таким потребам відповідає обсяг зерна на підприємствах від 6-7 млн т і більше. 
За даними Держстату України на початку 2021 року (станом на 1 січня) наявність культур зернових та зернобобових на підприємствах, що займа- ються їх зберіганням і переробленням, становить 7760,9 тис. т, що на 21,4 \% менше ніж у січні 2020 р. (табл.1).

Таблиця 1

Наявність культур зернових та зернобобових за звітний період 2021 р. (тис. т)*

\begin{tabular}{|c|c|c|c|c|}
\hline \multirow{2}{*}{ Сировина } & \multicolumn{2}{|c|}{$\begin{array}{l}\text { Наявність станом на } \\
01.012021 \text { р. }\end{array}$} & \multicolumn{2}{|c|}{$\begin{array}{l}\text { Наявність станом на } \\
\text { 01.07. } 2021 \text { p. }\end{array}$} \\
\hline & $\mathrm{T}$ & $\begin{array}{c}\text { y \% до відповідної } \\
\text { дати } 2020 \text { p. }\end{array}$ & $\mathrm{T}$ & $\begin{array}{c}\text { y \% до відповідної } \\
\text { дати } 2020 \text { р. }\end{array}$ \\
\hline $\begin{array}{l}\text { Культури зернові та зернобобові, } \\
\text { 3 них: }\end{array}$ & 7760,9 & 78,6 & 2151,0 & 115,4 \\
\hline пшениця & 1677,1 & 78,0 & 559,3 & 103,6 \\
\hline кукурудза на зерно & 5637,7 & 80,9 & 927,3 & 147,4 \\
\hline ячмінь & 259,8 & 43,8 & 575,2 & 89,2 \\
\hline жито & 87,3 & 183,0 & 56,9 & 191,3 \\
\hline овес & 7,7 & 135,2 & 3,9 & 93,4 \\
\hline гречка & 9,7 & 56,2 & 3,8 & 140,1 \\
\hline просо & 11,0 & 197,6 & 1,6 & 88,7 \\
\hline горох & 7,9 & 86,0 & 4,4 & 52,1 \\
\hline
\end{tabular}

*Складено авторами за даними Державної служби статистики України [10]

До липня місяця, тобто до збору нового урожаю, наявність зернових відповідно зменшилась, і станом на 01.07.21 становила 2151,0 тис. т, що на 15,4 \% більше до відповідного періоду минулого року.

Станом на 1 липня 2021 у порівнянні до відповідного періоду минулого року на підприємствах збільшилася наявність жита майже у 2 рази, кукурудзи на зерно - на 47,4 \%, гречки - на 40,1 \%, водночас зме- ншилась наявність гороху на 47,9 \%, проса - на 11,3\%. ( табл. 1).

Із загального обсягу зернових станом на 01.07. 2021 р. на підприємствах найбільше зберігалося кукурудзи на зерно - 927,3 тис. т (43,1 \%), ячменю - 575,2 тис. т (26,1 \%), пшениці - 559,3 тис. т (26,0 \%), жита - 56,9 тис. т (2,6\%) (рис. 2).

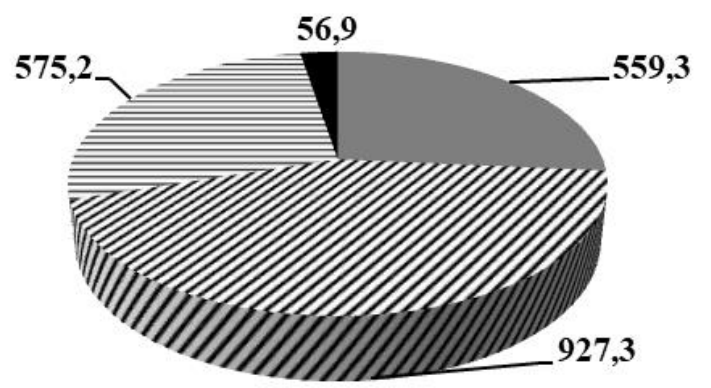

\author{
пшениця \\ \% кукурудза на зерно \\ इ ячмінь \\ ш жито
}

Рис. 2. Наявність основних зернових культур станом на 1 липня 2021 р. (тис. т)

*побудовано за даними Державної служби статистики України [10]

Показник наявності культур зернових та зернобобових по регіонах України у січні - червні 2021 p. знаходився в широкому діапазоні - від 574,6 тис. т у Одеській, 426,6 тис. т у Миколаївській областях до 1,7 тис. т у Донецькій та 7,8 тис. т у Житомирській областях (рис. 3.) [10].

Лідируючими регіонами зі збору зернових традиційно є Одеська, Миколаївська, Херсонська, Запорізька, Дніпропетровська, Кіровоградська, Київська області. Уже станом на 01 липня 2021 р. господарствами усіх категорій було зібрано 825,2 тис. т зернових та зернобобових.
Аналізуючи наявність зернових та зернобобових культур на переробних підприємствах можна сказати, що безпосередньо у місцях вирощування більш як 50 \% загального обсягу продукції рослинництва лишається для зберігання та переробки.

У міру насичення ринку та посилення конкуренції сільськогосподарські підприємства визначають обсяг продажу своєї продукції, так як рух товарів і коштів створює основу економічних відносин між виробниками, постачальниками, посередниками і покупцями. 


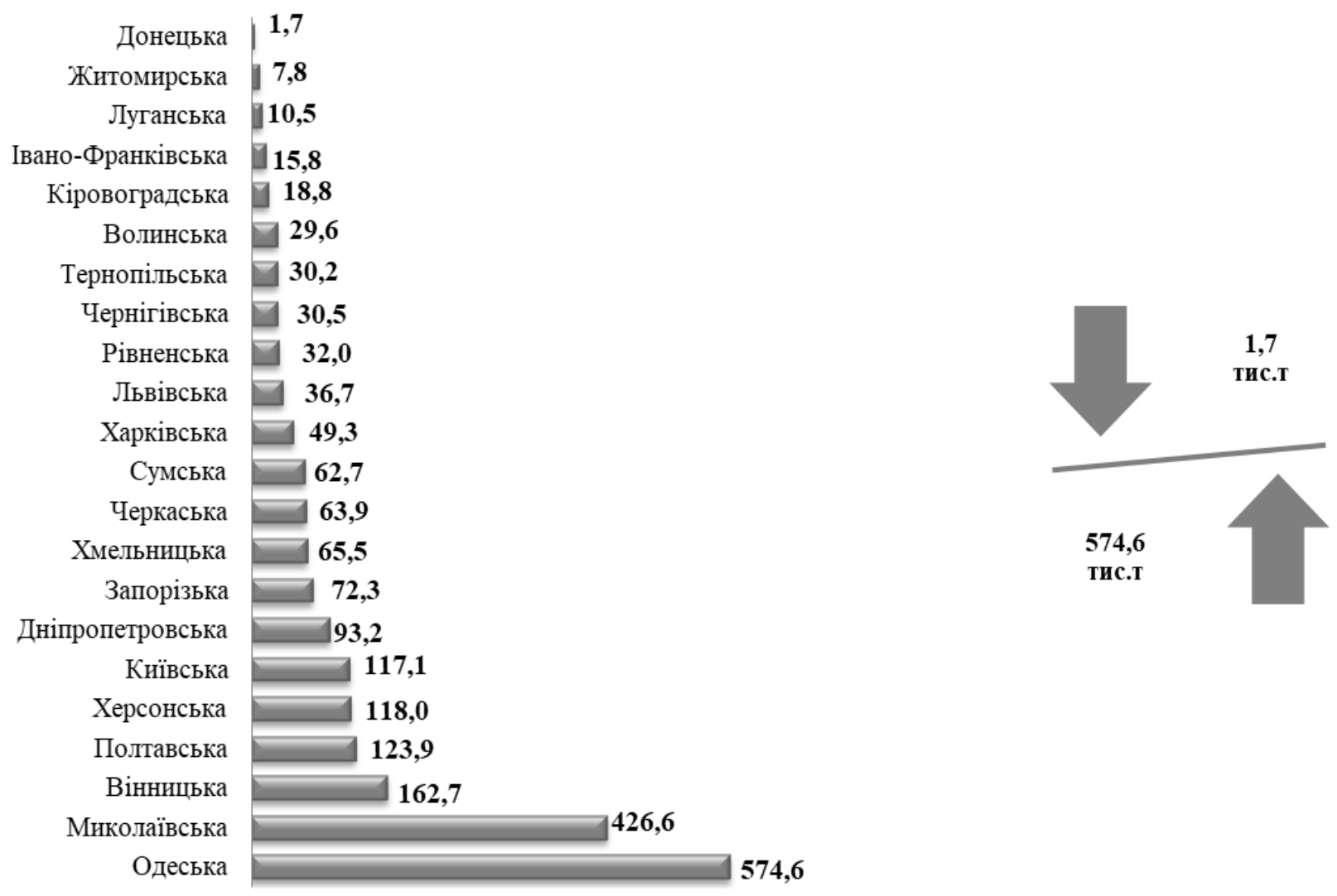

Рис. 3. Наявність культур зернових та зернобобових по регіонах, тис. т (січень - червень 2021 р.)* *побудовано за даними Державної служби статистики України [10].

Сільськогосподарські підприємства реалізують свою продукцію підприємствам, що займаються їхнім зберіганням і переробленням. Так за січень червень 2021 року було реалізовано зернових та зернобобових культур 12787,1 тис. т, що на 18,0 \% менше до відповідного періоду 2020 р. Середня ціни реалізації становила 6604,8 грн/т, що на 53,8 \% більше ніж у січні - червні 2020 р. (табл. 2).

Найбільше із зернових та зернобобових було реалізовано кукурудзи на зерно $-71,8 \%$ (9177,7 тис. т), пшениці - 22,2\% (2838,0 тис. т).

Таблиця 2

Обсяги та середні ціни реалізації основних зернових культур сільськогосподарськими підприсмствами у січні - червні 2021 р.*

\begin{tabular}{|l|c|c|c|c|}
\hline \multirow{2}{*}{$\begin{array}{c}\text { Найменування } \\
\text { продукції }\end{array}$} & \multicolumn{2}{|c|}{ Реалізовано, тис.т } & \multicolumn{2}{c|}{ Середні ціни реалізаціі, грн/т } \\
\cline { 2 - 5 } & $\begin{array}{c}\text { у січні- черв- } \\
\text { ні 2021 p. }\end{array}$ & $\begin{array}{c}\text { у \% до відповідного } \\
\text { періоду 2020 p. }\end{array}$ & $\begin{array}{c}\text { у січні-червні } \\
2021 \text { р. }\end{array}$ & $\begin{array}{c}\text { у до відповідного } \\
\text { періоду 2020 р. }\end{array}$ \\
\hline $\begin{array}{l}\text { Культури зернові та зернобобові, } \\
\text { з них: }\end{array}$ & 12787,1 & 82,0 & 6604,8 & 153,8 \\
\hline пшениця & 2838,0 & 79,9 & 6766,2 & 142,9 \\
\hline кукурудза на зерно & 9177,7 & 85,5 & 6561,0 & 158,4 \\
\hline ячмінь & 480,3 & 46,7 & 6212,1 & 157,9 \\
\hline жито & 76,1 & 229,8 & 4456,9 & 86,1 \\
\hline
\end{tabular}

*Складено авторами за даними Державної служби статистики України [10].

За період січень - червень 2021 р. у порівнянні до січня - червня 2020 р. збільшилася реалізація жита у 2,3 раза і становила 76,1 тис. т., реалізація ж усіх інших зернових зменшилася. Середні ціни реалізації навпаки збільшилися, за даний період найбільше зросли ціни на ячмінь на 57,9 \%, і становили 6212,1 грн/т., ціни на жито зменшилися на 13,9 \% до 4456,9 грн/т (табл. 2).
Із реалізованих сільськогосподарськими підприємствами культур зернових та зернобобових (12787,1 тис. т) у січні - червні 2021 р. підприємствами, що займаються їхнім зберіганням і переробленням, було куплено 2579,5 тис. т за середньою ціною 6809,0 грн/т. За даний період найбільше було куплено кукурудзи на зерно - 1118,2 тис. т за середньою ціною 6790,1 грн/т, далі пшениці - 1009,0 тис. т за 
середньою ціною 6830,7 грн/т. Із основних зернових культур найменше куплено жита - 17,3 тис. т за середньою ціною 4427,7 грн/т (табл. 3).

Середня ціна купівлі зернових у січні - червні зросла на 54,1 \% до відповідного періоду поперед- нього року. Найбільше середня ціна купівлі зросла на кукурудзу - 75,8 \%, що становить 6790,1 грн/т, знизилася ціна - на жито - на 20,2 \% (табл. 3).

Таблиця 3

Надходження основних зернових культур та середня ціна купівлі у січні - червні 2021 року*

\begin{tabular}{|l|c|c|c|}
\hline \multicolumn{1}{|c|}{$\begin{array}{c}\text { Культури зернові } \\
\text { та зернобобові }\end{array}$} & $\begin{array}{c}\text { Куплено з початку } \\
\text { року, тис. т }\end{array}$ & грн/т & у \% до січня - червня 2020 p. \\
\cline { 3 - 4 } $\begin{array}{l}\text { Всього, } \\
\text { з них }\end{array}$ & 2579,5 & 6809,0 & 154,1 \\
\hline пшениця & 1009,0 & 6830,7 & 143,5 \\
\hline кукурудза на зерно & 1118,2 & 6790,1 & 175,8 \\
\hline ячмінь & 354,4 & 6354,3 & 146,8 \\
\hline жито & 17,3 & 4427,7 & 79,8 \\
\hline
\end{tabular}

*Складено авторами за даними Державної служби статистики України [10]

По регіонах України діапазон середніх цін купівлі культур зернових та зернобобових у січні - червні
2021 р. знаходився в межах від 4550,1 грн/т у Одеській області до 7388,7 грн/т у Харківській області (табл. 4).

Таблиця 4

Середні ціни купівлі культур зернових та зернобобових по регіонах

у січні - червні 2021 р.*

\begin{tabular}{|c|c|c|}
\hline Область & $\begin{array}{c}\text { Середня ціна купівлі з } \\
\text { початку року, грн/т }\end{array}$ & $\begin{array}{c}\text { У \% до відповідного } \\
\text { періоду попереднього } \\
\text { року }\end{array}$ \\
\hline Харківська & 7388,7 & 140,2 \\
\hline Вінницька & 7152,0 & 160,3 \\
\hline Хмельницька & 6999,3 & 135,5 \\
\hline Чернігівська & 6991,1 & 153,4 \\
\hline Миколаївська & 6962,3 & 155,9 \\
\hline Україна & 6809,0 & 154,1 \\
\hline Кіровоградська & 6777,9 & 163,4 \\
\hline Рівненська & 6773,5 & 142,7 \\
\hline Луганська & 6766,9 & 152,2 \\
\hline Київська & 6743,5 & 150,2 \\
\hline Житомирська & 6737,4 & 167,4 \\
\hline Запорізька & 6705,8 & 152,2 \\
\hline Полтавська & 6684,5 & 166,0 \\
\hline Сумська & 6660,4 & 171,7 \\
\hline Львівська & 6657,4 & 162,5 \\
\hline Дніпропетровська & 6637,9 & 145,2 \\
\hline Херсонська & 6634,7 & 152,9 \\
\hline Тернопільська & 6630,7 & 163,6 \\
\hline Волинська & 6525,8 & 158,1 \\
\hline Черкаська & 6345,4 & 178,4 \\
\hline Одеська & 4550,1 & 110,6 \\
\hline
\end{tabular}

7388.7

грн/т

4550,1 грн/т
Відмічене, що за період січень - червень 2021 p. середні ціни купівлі культур зернових та зернобобових в цілому у всіх регіонах України виросли порівняно $з$ відповідним періодом минулого року. Найбільший ріст відмічено у Черкаській області - на 78,4 \%, найменший - 10,6 \% - у Одеській області. У п'яти областях середні ціни купівлі були вищі від середніх цін по Україні. (табл. 4).

Переробленням зернових та зернобобових культур на борошномельно-круп'яну продукцію за дани- ми Держстату за 2019 р. займається 1500 підприємств різних форм власності.

За офіційними даними Держстату України у січні - червні 2021 р. усього перероблено культур зернових та зернобобових 2026,0 тис. т, що на 13,8\% менше до відповідного періоду минулого року. Загалом обсяг перероблення зернових культур зменшується, так у порівнянні до відповідного періоду минулого року обсяг переробки пшениці зменшився на 28,0 \% , ячменю - на 18,6 \%, кукурудзи -на 2,5 \% (табл. 5). 
Загальний обсяг перероблених зернових та зернобобових за основними культурами у січні - червні 2021 р.*

\begin{tabular}{|c|c|c|c|c|c|c|c|}
\hline \multirow{2}{*}{$\begin{array}{c}\text { Усього пе- } \\
\text { рероблено } \\
\text { зернових, } \\
\text { тис. т }\end{array}$} & \multirow{2}{*}{$\begin{array}{l}\text { У \% до відповід- } \\
\text { ного періоду по- } \\
\text { переднього року }\end{array}$} & \multicolumn{3}{|c|}{$\begin{array}{c}\text { Із загального обсягу перероблено за ку- } \\
\text { льтурами, тис. т }\end{array}$} & \multicolumn{3}{|c|}{$\begin{array}{c}\text { У \% до відповідного періоду } \\
\text { попереднього року }\end{array}$} \\
\hline & & пшениця & кукурудза & ячмінь & пшениця & кукурудза & ячмінь \\
\hline 2026,0 & 86,2 & 648,6 & 1067,4 & 190,5 & 72,0 & 97,5 & 81,4 \\
\hline
\end{tabular}

*Складено авторами за даними Державної служби статистики України [10]

Із загального обсягу зернових у січні червні 2021 р. найбільше перероблено кукурудзи - 1067,4 тис. т, що складає 52,7 \%, на пшеницю припадає 32,0 \% 648,6 тис. т, частка ячменю становить 9,4\% - 190,5 тис. т.

Із перероблених зернових та зернобобових культур (2026,0 тис. т) у січні - червні 2021 р. було вироблено комбікорму 858,2 тис. т, що складає 42,4 \%, борошна 521,2 тис. т $(25,7 \%)$, крупи - 117,0 тис. т $(5,8 \%)$. У порівнянні до відповідного періоду минулого року збільшилося перероблення зернових культур на крупу (на 14,1 \%), зменшилося на борошно - на 30,0 \% та комбікорм - на 7,5 \% (табл. 6).

Таблиця 6

Перероблення культур зернових та зернобобових за основними продуктами у січні - червні 2021 р.*

\begin{tabular}{|c|c|c|c|c|c|c|c|c|}
\hline \multirow{3}{*}{ Сировина } & \multicolumn{4}{|c|}{ Перероблено з початку року, тис.т } & \multicolumn{4}{|c|}{$\begin{array}{c}\text { У \% до відповідного періоду } \\
\text { попереднього року }\end{array}$} \\
\hline & \multirow{2}{*}{ усього } & \multicolumn{3}{|c|}{3 нього на: } & \multirow{2}{*}{ усього } & \multicolumn{3}{|c|}{3 нього на: } \\
\hline & & борошно & крупу & комбікорм & & борошно & крупу & комбікорм \\
\hline $\begin{array}{l}\text { Культури зер- } \\
\text { нові та зерно- } \\
\text { бобові }\end{array}$ & 2026,0 & 521,2 & 117,0 & 858,2 & 86,2 & 70,0 & 114,1 & 92,5 \\
\hline
\end{tabular}

*Складено авторами за даними Державної служби статистики України [10]

За Даними Держстату України у січні - червні 2021 р. було перероблено на борошно: пшениці - 503,3 тис. т, що на 29,6 \% менше до відповідного періоду минулого року; жита - 16,9 тис. т, (на 42,5 \% менше ніж у відповідному періоді минулого року). На крупу перероблялися: горох - 27,7 тис. т (менше на 4,6 \% до відповідного періоду минулого року), гречка - 25,3 тис. т, (менше на 22,5 \% ніж у січні - червні 2021 р.), овес - 22,7 тис. т, (у 4.3 рази більше ніж за відповідний період минулого року), пшениця - 14,8 тис. т (до відповідного періоду минулого року більше на 2,1 \%), просо - 7,9 тис. т, (більше на 11,5 \% ніж у відповідному періоді минулого року) та жито - 0,3 тис. т, (на 2,5 \% більше ніж у січні - червні 2021 р.). На комбікорм перероблялися: кукурудза - 733,1 тис. т, що на 7,8 \% менше до відповідного періоду минулого року; пшениця - 111,2 тис. т, що 3,9 \% менше ніж у відповідному періоді минулого року; ячмінь - 10,8 тис. т (до відповідного періоду минулого року менше на $24,3 \%$ ), горох - 1,0 тис. т (майже у 1,5 рази менше ніж у відповідному періоді минулого року), жито - 0,5 тис. т (на 30,2 \% більше до відповідного періоду минулого року), овес - 0,2 тис. т (більше на 3,2 \% до відповідного періоду минулого року) (рис. 4).

Виробничі потужності зернової галузі України представлені у всіх регіонах країни, проте лідерами 3 переробки зернових та зернобобових культур є Вінницька, Дніпропетровська, Київська, Харківська, Черкаська та Хмельницька області, що переробляють в сукупності більше половини всього обсягу зернових.

Так у січні - червні 2021 р. найбільше перероблено зернових та зернобобових культур у Вінницькій області - 400,9 тис. т, що на 10,4 \% менше ніж у відповідному періоді минулого року, Дніпропетровській - 337,4 тис. т (на 13.1 \% менше до відповідному періоді минулого року), Київській - 287, 0 тис. т (на $10.3 \%$ більше до відповідному періоді минулого року) областях (рис. 5). 

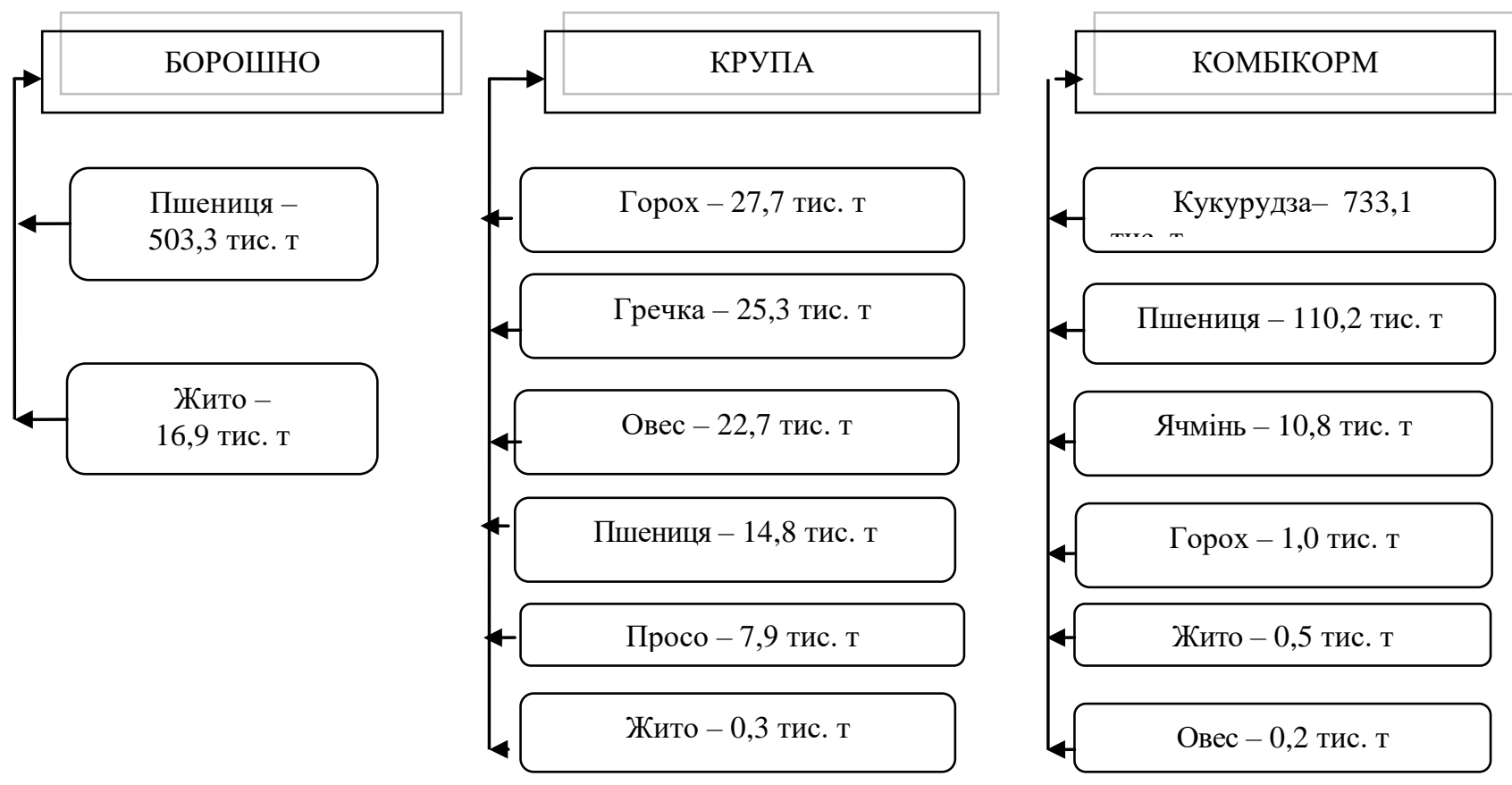

Рис. 4. Обсяг перероблення зернових на борошно, крупу, комбікорм у січні - червні 2021 р.*

*побудовано авторами за даними Державної служби статистики України

Найменше перероблено зернових та зернобо- ганській - 10,0 тис. т областях (рис. 5). бових культур у Кіровоградській - 0,8 тис. т та Лу-

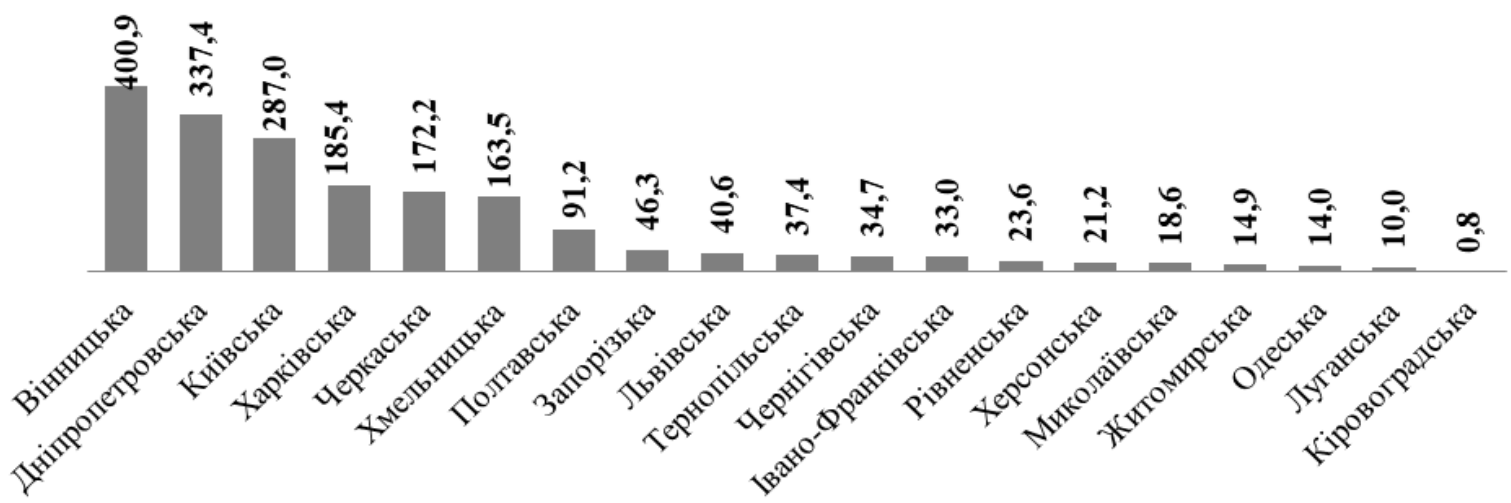

Рис. 5. Перероблення культур зернових та зернобобових по регіонах, тис. т (січень - червень 2021 р.)* *побудовано авторами за даними Державної служби статистики України

Таким чином, найбільші об'єкти зернової галузі територіально розташовані між основними джерелами сировини (зерновими) і основними переробниками та споживачами готової продукції.

Основним споживачем зернової галузі України є борошномельно-круп'яна промисловість (зернова складова понад 70\%), обсяги та якість виробництва готової борошномельно-круп'яної продукції залежить від постачання зернових видів сировини, які є невід'ємною складовою для забезпечення безперебійного виробництва [5].

В Україні борошно $є$ сировиною для най - більш важливих продуктів харчування, а крупи являються традиційним українським продуктом і завдяки своїй високій поживності відрізняються стабільним широким споживанням.

За останні роки відмічено спад виробництва борошномельно-круп'яної продукції. За офіційними даними Держстату за три останні роки 32018 р. по 2020 р. виробництво борошна зменшилося на $21,4 \%$ i становить 1372, 4 тис. т. За січень - червень 2021 р. у порівнянні до відповідного періоду минулого року виробництво борошна знизилося на 165,8 тис. т. (рис. $6)$. 


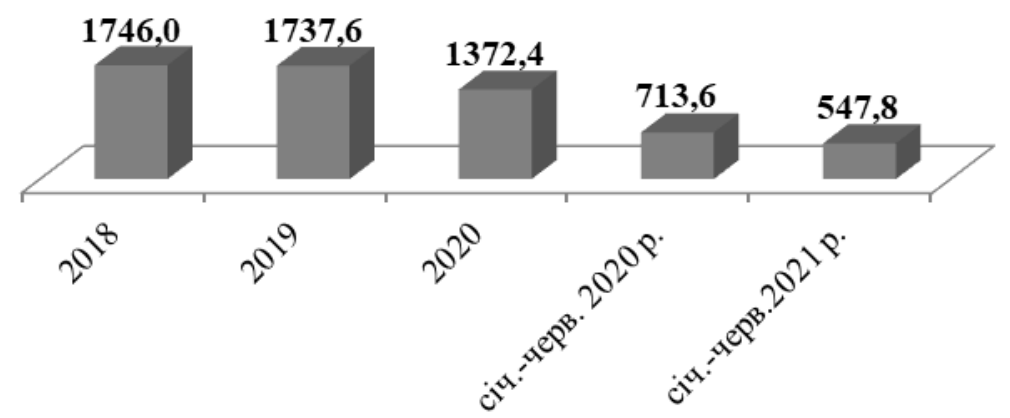

Рис. 6. Динаміка виробництва борошна (пшеничного, пшенично-житнього), тис.т* *побудовано авторами за даними Державної служби статистики України

Динаміка виробництва круп за останні три роки свідчить про те, що їх виробництво є стабільним, і знаходиться в межах 67,6 - 67,9 тис. т. Вироб- ництво круп у січні - червні 2021 р. зменшилося на 1,2 тис. т і становило 33,9 тис. т (рис.7).

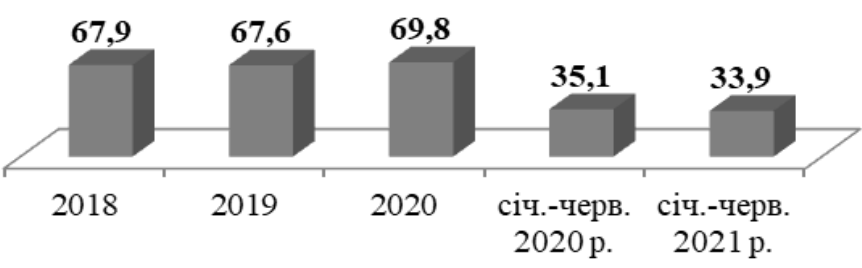

Рис. 7. Динаміка виробництва круп*

*побудовано авторами за даними Державної служби статистики України

Стосовно інших продуктів борошномельнокруп'яної промисловості, слід зазначити, що за перше півріччя 2021 року також відбулося зменшення виробництва, зокрема борошна 3 культур інших зернових - на 43,3\%, рису вибіленого на $11,9 \%$, зерен зернових культур плющених - на 2, 1\% (табл. 7).

Таблиця 7

Виробництво основних видів продукції борошномельно-круп'яної промисловості у січні - червні 2021 р.*

\begin{tabular}{|c|c|c|c|c|c|}
\hline \multirow{2}{*}{ Найменування продукції } & \multicolumn{2}{|c|}{$\begin{array}{c}\text { Кількість виробленої } \\
\text { промислової продук- } \\
\text { ції, тис.т }\end{array}$} & \multirow{2}{*}{$\begin{array}{l}\text { Червень } \\
2021 \text { p.y \% } \\
\text { до червня } \\
2020 \text { p. }\end{array}$} & \multirow{2}{*}{$\begin{array}{c}\text { Січень- } \\
\text { червень } \\
2021 \text { р. у } \\
\text { \% до січ- } \\
\text { ня-червня } \\
2020 \text { р. }\end{array}$} & \multirow{2}{*}{$\begin{array}{c}\text { Кількість запасів } \\
\text { продукції на } \\
\text { складах підпри- } \\
\text { ємств на кінець } \\
\text { червня } 2021 \text { р., } \\
\text { тис. т }\end{array}$} \\
\hline & $\begin{array}{l}\text { червень } \\
2021 \text { p. }\end{array}$ & $\begin{array}{l}\text { січень- } \\
\text { червень } \\
2021 \text { р. }\end{array}$ & & & \\
\hline $\begin{array}{l}\text { Борошно пшеничне чи пшенично- } \\
\text { житнє }\end{array}$ & 87,4 & 547,8 & 80,8 & 75,2 & 44,1 \\
\hline Борошно з культур зернових інших & 3,4 & 21,0 & 69,2 & 56,7 & 1,7 \\
\hline Крупи & 5,7 & 33,9 & 95,6 & 99,2 & 2,7 \\
\hline $\begin{array}{l}\text { Зерна зернових культур плющені, пе- } \\
\text { рероблені в пластівці, лущені, обруше- } \\
\text { ні, різані або подрібнені }\end{array}$ & 15,3 & 86,8 & 137,2 & 97,9 & 10,1 \\
\hline $\begin{array}{l}\text { Рис вибілений напівобрушений чи } \\
\text { повністю обрушений }\end{array}$ & 0,9 & 7,3 & 101,2 & 88,1 & 0,3 \\
\hline
\end{tabular}

*Складено авторами за даними Державної служби статистики України [10]

Найбільша кількість запасів виробленої продукції на складах підприємств на кінець червня 2021 р. припадає на борошно - 44,1 тис. т.

Основне виробництво круп та борошна в Україні зосереджене в зонах вирощування зернової сировини та споживання. Значні обсяги борошна виробляються на підприємствах Харківської, Запорізької, Київської областей. 
У регіональному зрізі стосовно виробництва продукції борошномельно-круп'яної промисловості у Держстаті України найповніше оприлюднені дані щодо виробництва борошна пшеничного (пшеничножитнього). Так за січень - червень 2021 p. Держстатом надана інформація по 12 областях.

За даний період найбільше було вироблено борошна у Харківській області - 90,2 тис. т, що на 8,7 $\%$ менше у порівнянні 3 відповідним періодом минулого року та Дніпропетровській - 45,7 тис. т, що на 43,4 \% менше до відповідного періоду минулого року, найменше вироблено борошна у Тернопільській та Донецькій областях (відповідно 9,2 і 9,9 тис. т). (табл. 8).

Таблиця 8

Виробництво борошна пшеничного (пшенично-житнього) по регіонах у січні - червні 2021 р.*

\begin{tabular}{|c|c|c|}
\hline Область & $\begin{array}{c}\text { Кількість виробленого } \\
\text { борошна у січні - червні 2021 р., тис. т }\end{array}$ & $\begin{array}{c}\text { Січень - червень 2021 p. } \\
\text { у \% до січня - червня 2020 p. }\end{array}$ \\
\hline Харківська & 90,2 & 91,3 \\
\hline Дніпропетровська & 45,7 & 56,6 \\
\hline Запорізька & 29,5 & 81,9 \\
\hline Київська & 27,3 & 61,0 \\
\hline Львівська & 19,8 & 70,3 \\
\hline Одеська & 16,1 & 87,3 \\
\hline Херсонська & 14,3 & 102,7 \\
\hline Луганська & 12,8 & 89,2 \\
\hline Полтавська & 12,8 & 127,8 \\
\hline Миколаївська & 11,2 & 171,6 \\
\hline Донецька & 9,9 & 63,4 \\
\hline Тернопільська & 9,2 & \\
\hline
\end{tabular}

*Складено авторами за даними Державної служби статистики України [10]

За січень - червень 2021 р. у порівнянні 3 відповідним періодом минулого року виробництво борошна збільшилося у трьох областях: Донецькій - у 1,7 раза, Миколаївській - на 27,8 \%, Луганській - на $2,7 \%$. У решті областей відбулося зниження виробництва борошна (табл. 8).

В інтерв'ю АПК-Інформ з Родіоном Рибчинським, директором ГС «Борошномели України», відмічено, що спілкуючись з учасниками аграрного ринку України щодо особливостей 2020/21 МР, від усіх без винятку звучить фраза про те, наскільки складним і непередбачуваним він видався. Борошномельна галузь в поточному сезоні зіткнулася зі специфічними проблемами: різке падіння обсягів виробництва через високу вартість сировини та експорту, триваюча стагнація внутрішнього попиту, імпорт пшениці з Білорусі і присутність імпортного пшеничного борошна на i без того висококонкурентному внутрішньому ринку, невідповідності ставки ПДВ при закупівлі сировини та реалізації продукції. Цей сезон чергового разу нагадав про необхідність диверсифікації та хеджування ризиків, а також про важливість вертикальної інтеграції компанії [11].

Виробництво борошна та круп в основному зосереджене в вертикально інтегрованих структурах, до яких входять сільськогосподарські підприємства (виробники зернової сировини), переробні підприємства (виробництво борошна, круп та іншої продукції). Готові вироби реалізується через власну торгівельну мережу під відомими серед населення марками. На сьогоднішній день спостерігаємо злиття і поглинання суб'єктів малого підприємництва та місцевих дрібних гравців ринку ключовими групами вертикальної інтеграції.

Портал «Зберігання та переробка зерна» за підтримки асоціації «Борошномели України» склав рейтинг провідних виробників борошна України за підсумками 2019/20 МР. Основні Топ-10 провідних виробників борошна наведено в табл. 9 [12].

Таблиця 9

Основні ТОП-10 провідних виробників борошна за підсумками 2019/20 МР*

\begin{tabular}{|c|l|c|}
\hline $\begin{array}{c}\text { № } \\
\text { 3/п }\end{array}$ & \multicolumn{1}{|c|}{ Назва підприємства } & $\begin{array}{c}\text { Частка } \\
\text { на ринку, \% }\end{array}$ \\
\hline 1 & $\begin{array}{l}\text { ТОВ «Вінницький комбінат хлібопродуктів №2», } \\
\text { входить в структуру «УКРПРОМІНВЕСТ-АГРО». }\end{array}$ & 11 \\
\hline 2 & ТОВ «Столичний млин», м. Київ & 7 \\
\hline 3 & $\begin{array}{l}\text { ТОВ «Дніпромлин», } \\
\text { входить до компанії Ristone Ноldings, м. Дніпро }\end{array}$ & 6 \\
\hline 4 & ТОВ КВФ «Рома», Харківська обл., м. Первомайський & 5 \\
\hline 5 & ТОВ «Хмельницьк-Млин», Хмельницька обл. & 4 \\
\hline
\end{tabular}


Продовження табл. 9

\begin{tabular}{|c|l|c|}
\hline $\begin{array}{c}\text { № } \\
\text { 3/п }\end{array}$ & Назва підприємства & $\begin{array}{c}\text { Частка } \\
\text { нанку, \% }\end{array}$ \\
\hline 6 & ПАТ «Кролевецький комбінат хлібопродуктів»- філія ДПЗКУ, Сумська обл. & 4 \\
\hline 7 & ДП «Новопокровський комбінат хлібопродуктів», Харківська обл., Чугуївський р-н. & 3 \\
\hline 8 & ТОВ «Васильківський комбінат хлібопродуктів», Київська обл. & 3 \\
\hline 9 & ТОВ «Енліль», м. Харків & 3 \\
\hline 10 & ТОВ «Рівне-Борошно», м. Рівне & 2 \\
\hline \multicolumn{2}{|c|}{ *Складено авторами за даними джерела [12] }
\end{tabular}

Підприємства мають виробляти тільки ті товари і в такому обсязі, які можна реально й прибутково реалізувати. У міру насичення ринку та посилення конкуренції вже не виробництво визначає обсяг продажу, а навпаки - можливий обсяг продажу є основою розроблення виробничої програми підприємства. Рух товарів і коштів створює основу економічних відносин між виробниками, постачальниками, посередниками і покупцями.

Однією зі специфічних особливостей ринку борошномельно-круп'яної продукції $\epsilon$ те, що його товари відносяться до продукції щоденного попиту і вирізняються високими вимогами щодо їхньої якості, зберігання, транспортування, споживання; відзначаються наявністю масового попиту, обмеженим періодом їх реалізації та іншими особливостями.

Проведені дослідження показали, що ефективний розвиток та функціонування вітчизняної борошномельно-круп'яної галузі залежить від обсягів постачання зернової сировини сільськогосподарськими підприємствами, надходження її на переробні підприємства, її виробництва та споживання.

Висновки та перспективи подальших досліджень. Першочерговим завданням держави $\epsilon$ гарантування продовольчої безпеки населення, тому формування достатніх запасів зерна і продуктів його переробки є пріоритетним напрямом діяльності Уряду. Відповідно галузі, що займаються зберіганням та переробленням зернової сировини, відіграють провідну роль у забезпеченні населення продуктами харчування.
На сьогодні підприємства з перероблення зернових знаходяться в складних економічних умовах. Проблемними питаннями є підвищення вартості сировини, зниження обсягів реалізації основних зернових культур сільськогосподарськими підприємствами на переробні підприємства і обсягів перероблення цих культур, нестабільність або й зниження попиту на готову продукцію, імпорт пшениці й борошна. Ці чинники у підсумку зумовили зниження виробництва борошномельно-круп'яної продукції в Україні.

Для ефективного функціонування галузі зберігання та переробки зернової сировини важливо економічно виважено вирішувати питання організації відносин між виробником, переробником і споживачем - підприємствами із вирощування і зберігання зернової сировини, переробними підприємствами, торговельними організаціями. Як актуальний захід ефективної організації виробничої діяльності у сфері нарощування продуктів харчування й збільшення випуску сировини для переробної галузі пропонується широке застосування вертикальної інтеграції, формування високотехнологічних професійних об'єднань і корпоративних структур. Міжгалузеві виробничі зв'язки у сфері виробництва та переробки зернових повинні вийти на новий, системний рівень для забезпечення їх дієвого взаємовигідного функціонування. В перспективі подальших досліджень моніторинг внутрішнього агропродовольчого ринку та пошук нових можливостей його результативної діяльності.

\section{Література}

1. Трофімцева О. Зернове господарство України стає все більш ефективним і продуктивним // Інформаційне агентство «AgroNews.ua»: електрон. версія. Новини 2021. 27 трав. URL: https://agravery.com/uk/posts/show/zernove-gospodarstvo-ukraini-stae-vse-bils-efektivnim-i-produktivnim-trofimceva (дата звернення: 10.06.2021)

2. Калетнік Г. М., Пепа Т. В., Ціхановська В. М.Територіальна організація зернопродуктового комплексу регіону та напрями його удосконалення: монографія / Вінниц. нац. аграр. ун-т. Вінниця: Вінницька газета, 2010. $180 \mathrm{c}$.

3. Подпрятов Г. І., Рожко В.І., Скалецька Л.Ф. Технологія зберігання та переробки продукції рослинництва: підручник. Київ: Аграрна освіта. 2014. 393 с.

4. Лебідь В. М., Прищепа К. С. Сучасний стан ринку зерна України, проблеми та перспективи розвитку // Економічний вісник Донбасу. 2013. № 1 (31) С. 131-135.

5. Кудренко Н. В. Сстан та перспективи розвитку борошномельно-круп'яної галузі України // Інтелект XXI. 2014. № 6. С. 22-29.

6. Князєв С. І. Ефективність розвитку борошномельно-круп'яної і комбікормової промисловості в Україні: автореф. дис. ... канд. екон. наук: 08.07.01: захист 09.12.2002 / наук. кер. Борщевський П.П. Київ: НАН України, Рада по вивч. продукт. сил України. 2002. 21 с. 
7. . Царьов В. М. Сучасний стан та перспективи розвитку підприємств борошномельної галузі України / ДВНЗ «Київський національний університет ім. Вадима Гетьмана». Київ. 2007. С. 105-113. URL: https://core.ac.uk/download/pdf/43283322.pdf ( дата звернення 25.05. 2021).

8. Ляховська О. В. Підприємства борошномельної промисловість України: актуальний стан та перспективи розвитку / ДУ «Інститут регіональних досліджень ім. М. I. Долішнього НАН України». Львів. 2019 C.1-2. URL.: https://conf.ztu.edu.ua/wp-content/uploads/2019/12/249.pdf (дата звернення 25.05. 2021).

9. Врожай зернових 2021: прогнози, ціни, перспективні ринки збуту та аналіз форвардних угод: вебсайт. URL: https://agropolit.com/spetsproekty/883-vrojay-zernovih-2021-prognozi-tsini-perspektivni-rinki-zbutu-ta-analizforvardnih-ugod (дата звернення 11.06. 2021).

10. Державна служба статистики України. [Веб-сайт]. Київ. 2021.URL: http://www.ukrstat.gov.ua/ (дата звернення 19.07- 23.07. 2021).

11. Складний 2020/21 МР приведе до чергової трансформації галузі - «Борошномели України» // АПКИнформ. Київ. 2021. ИТОГИ №6 (84) URL: https://www.apk-inform.com/uk/exclusive/opinion/1520687 (дата 3вернення 02.07. 2021).

12. Hipzmag.com: [научно-практический портал «Хранение и переработка зерна»]. Київ, 2021. URL: https://hipzmag.com/o-portale/ (дата звернення 11.06. 2021).

Стаття надійшла 10.07.2021

Стаття прийнята до друку 24.07.2021

Доступно в мережі Internet 24.10.2021

Polonska O.

Senior Researcher

Research Department of Productivity and Analytics of Statistical Reporting in Food and Processing Industry E-mail: olga_polon3@ukr.net ORCID ID: 0000-0002-2432-8540
Soloshonok A.

Head of Research Department of Productivity and Analytics of Statistical Reporting in Food and Processing Industry E-mail: 555860@ukr.net ORCID ID: 0000-0001-8354-7519

\author{
Nekova G. \\ Researcher \\ Research Department of Productivity and Analytics of Statistical Reporting \\ in Food and Processing Industry \\ Ukrainian Research Institute of Agricultural Productivity \\ Sq. Solomyanska, Kyiv, 203035 \\ E-mail: smilealiona@ukr.net \\ ORCID ID: 0000-0001-6797-4502
}

\title{
ANALYSIS OF CEREALS TURNOVER AND PRODUCTION OF FLOUR- GRINDING PRODUCTS IN UKRAINE
}

The state of receipt, availability, processing of grain and leguminous crops at enterprises engaged in their storage and processing for the first half of 2021 has been reflected in total in Ukraine and in the regional cut. During this period, the volumes and average selling prices of agricultural enterprises of the main grain and leguminous crops (wheat, corn for grain, barley, rye) were analyzed, and the forecast data on the grain harvest in 2021 were also highlighted. The receipts of the main grain crops to processing enterprises and the average prices of their purchase in Ukraine and the regions were formed in the table and analyzed. An analysis has been made of the total volume of processed cereals and legumes for the main crops (wheat, corn, barley) and the volume of processing of cereals and legumes for the main products (flour, cereals, mixed feed) for the first half of 2021 compared to the corresponding period of the last year. The scheme of processing and consumption of flour-grinding products has been given. The volume of production of the main types of flour and cereals products and the dynamics of the production of flour and cereals for the last three years have been analyzed. The regional cut shows the amount of flour produced in the first half of 2021. In Ukraine, flour is a raw material for the most important foodstuffs, and cereals are a traditional Ukrainian product and, due to their high nutritional value, are characterized by stable wide consumption. In general, the specific problems of the flour-grinding industry and the ways of their solution have been disclosed. The rating of Top-10 leading flour producers in Ukraine has also been given.

Key words: food security, grain and leguminous crops, receipt, sale, processing, flour-grinding products, average price, production. 


\section{References}

1. Trofimtseva, O. (2021). Zernove hospodarstvo Ukrainy staie vse bilsh efektyvnym i produktyvnym. Informatsiine ahentstvo "AgroNews.ua». Retrieved June 10, 2021, from https://agravery.com/uk/posts/show/zernovegospodarstvo-ukraini-stae-vse-bils-efektivnim-i-produktivnim-trofimceva

2. Kaletnik, H. M., Pepa, T. V., \& Tsikhanovska, V. M. (2010). Terytorialna orhanizatsiia zernoproduktovoho kompleksu rehionu ta napriamy yoho udoskonalennia. Vinnyts. nats. ahrar. un-t. / Vinnytska hazeta.

3. Podpriatov, H. I., Rozhko, V. I., \& Skaletska, L. F. (2014). Tekhnolohiia zberihannia ta pererobky produktsii roslynnytstva. Ahrarna osvita.

4. Lebid, V. M., \& Pryshchepa, K. Ye. (2013). Suchasnyi stan rynku zerna Ukrainy, problemy ta perspektyvy rozvytku. Ekonomichnyi visnyk Donbasu, (1 (31)), 131-135.

5. Kudrenko, N. V. (2014). Stan ta perspektyvy rozvytku boroshnomelno-krup'ianoi haluzi Ukrainy. Intelekt $X X I,(6), 22-29$.

6. Kniaziev, S. I. (2002). Efektyvnist rozvytku boroshnomelno-krupianoi i kombikormovoi promyslovosti v Ukraini (thesis abstract; kand. ekon. nauk: 08.07.01: zakhyst 09.12.2002; nauk. ker. Borshchevskyi P.P.). NAN Ukrainy, Rada po vyvch. produkt. syl Ukrainy, Kyiv.

7. Tsarov V. M. (2007). Suchasnyi stan ta perspektyvy rozvytku pidpryiemstv boroshnomelnoi haluzi Ukrainy. DVNZ «Kyivskyi natsionalnyi universytet im. Vadyma Hetmana», 105-113. URL: Retrieved May 25, 2021, from https://core.ac.uk/download/pdf/43283322.pdf

8. Liakhovska, O. V. (2019). Pidpryiemstva boroshnomelnoi promyslovist Ukrainy: aktualnyi stan ta perspektyvy rozvytku. DU «Instytut rehionalnykh doslidzhen im. M. I. Dolishnoho NAN Ukrainy», 1-2. Retrieved May 25, 2021, from https://conf.ztu.edu.ua/wp-content/uploads/2019/12/249.pdf

Vrozhai zernovykh 2021: prohnozy, tsiny, perspektyvni rynky zbutu ta analiz forvardnykh uhod. Retrieved June 11, 2021, from https://agropolit.com/spetsproekty/883-vrojay-zernovih-2021-prognozi-tsini-perspektivni-rinki-zbututa-analiz-forvardnih-ugod

10. Derzhavna sluzhba statystyky Ukrainy. Retrieved July 23, 2021, from http://www.ukrstat.gov.ua/

11. Skladnyi 2020/21 MR pryvede do cherhovoi transformatsii haluzi - «Boroshnomely Ukrainy». (2021). APK-Ynform, (6 (84)) Retrieved July 02, 2021, from https://www.apk-inform.com/uk/exclusive/opinion/1520687

12. Nauchno-praktycheskyi portal «Khranenye y pererabotka zerna». Retrieved June 11, 2021, from https://hipzmag.com/o-portale/

Received 10 July 2021

Approved 24 July 2021

Available in Internet 24.10.2021

Цитування згідно ДСТУ 8302:2015

Полонська О.М., Солошонок А.Л., Некова Г.П. Аналіз обігу зернових та виробництва борошномельнокруп'яної продукції в Україні // Економіка харчової промисловості. 2021. Т. 13, вип. 3. С. 34-45. doi: 10.15673/fie.v13i3.2130

Cite as APA style citation

Polonska, O., Soloshonok, A., \& Nekova, G. (2021). Analysis of cereals turnover and production of flour-grinding products in Ukraine. Food Industry Economics, 13(3), 34-45. doi: 10.15673/fie.v13i3.2130 